Liana Chua

Department of Anthropology, Brunel University, London

48 Pretoria Road, Cambridge, CB4 1HE, United Kingdom

44-1895-265429 (O), 44-7773-104562

liana.chua@cantab.net 


\section{Gifting, dam(n)ing and the ambiguation of development in Malaysian Borneo}

\section{Abstract:}

This article seeks to move beyond the critical politicising impulse that has characterised anthropologies of development since the 1990s towards a more open-ended commitment to taking seriously the diverse moral and imaginative topographies of development. It explores how members of four small Bidayuh villages affected by a dam-construction and resettlement scheme in Sarawak draw on both historically inflected tropes of gifting and Christian moral understandings in their engagements with Malaysia's peculiar brand of state-led development. These enable the affected villagers not to resolve the problems posed by Malaysian developmentalism, but to ambiguate them and actually hold resolution at bay. I conclude by considering the implications of such projects of ambiguation for the contemporary anthropology of development.

Keywords:

development, ambiguation, gifting, Christianity, Malaysian Borneo

This work was supported by the British Academy Small Grants Scheme under Grant SG 50254. 
A few years after construction commenced on a dam due to displace four small Bidayuh villages, one of its chief advocates — a prominent Bidayuh politician — was diagnosed with cancer. Although he eventually recovered, his illness precipitated speculative rumblings within the affected communities about how God was punishing him for his aggressive promotion of the scheme. This individual had been the political face of the project, and his preliminary visits to the villages - replete with promises about compensation, relocation and infrastructural improvements - were closely watched, remembered and recorded on film and mobile phones. Perhaps it was no surprise, then, that most people blamed him for the problems that had since blighted the proceedings, including inadequate compensation, incursions onto individuals' farmlands and the non-materialization of a safe walking route through the construction site. Yet while complaining about his 'nakar' (mischief-making) behaviour, many villagers were redoubling their efforts to secure his tutelage and remind him of his unfulfilled promises. Both the chief villain and potential redeemer of the story, this politician remained a beacon of hope in a situation for which he was at least partially culpable.

This brief sketch encapsulates the jumble of anxieties, aspirations and dilemmas that form my article's ethnographic core: Bidayuhs' relationships with state-led development. The politician's illness constituted one of many moments when two key moral frameworks — gifting mythology and Christian ethics — came together to shape my acquaintances' engagements with the 'power matrices' (Li 2007:288) of development and the state. Crucially, they did so not by alleviating people's anxiety and uncertainty over recent events, but by ambiguating the problems and failures of Malaysia's peculiar brand of development, thereby keeping my acquaintances' hope and faith in its promises alive. In the process, they transformed development itself, turning the dam-construction and resettlement scheme into a site of moral, temporal and spiritual possibility. 
Until relatively recently, topics such as myth, ritual and spirituality were deemed irrelevant or even inimical to both development practice and theory (ver Beek 2000). But as anthropologists have increasingly recognized, this assumption-premised on a modern Western division between the secular and religious (Bornstein 2005:3) - can obscure the entanglements of religious ideas, faith and development on the ground. This article explores one such set of entanglements in the hills of Malaysian Borneo, with the wider aim of helping to nudge the anthropology of development 'beyond critique', as Yarrow and Venkatesan have recently proposed (2012:8). More than highlighting how myths, religion and suchlike influence people's engagements with development, I advocate an analytical shift away from a politicizing impulse that, I argue, has dominated recent anthropologies of development, towards a more open-ended commitment to taking seriously its diverse moral and cosmological topographies.

By 'politicizing impulse', I refer to an analytical tendency popularised by post-structuralist critiques of development in the 1990s and that has since become a defining characteristic of the subfield. Fuelled by a Foucauldian sensibility, the works of Arturo Escobar (2012 [1995]), James Ferguson (1990) and others (e.g. Crush 1995; Grillo and Stirrat 1997; Sachs 1992) entailed a much-needed deconstruction of the ostensibly apolitical, progressive discourses of international development, showing how they were in fact profoundly political, often perpetuating and forging new inequalities and normalities. Such 'exposés' (High 2014:3) expanded rather than delimited the field of 'the political', showing how hegemonic development discourses transcended formal institutional structures, producing their own power-saturated world of knowledge, action and subjecthood. These scholars' efforts were instrumental in turning the anthropology of development into a critical enterprise that interrogated the discourses of development, 'unmasking ... the political relations that underlie surface representations' (Yarrow and Venkatesan 2012:3) in what was itself a political scholarly act (e.g. Escobar 2012:14). 
Since the 1990s, the anthropology of development has been shaped by myriad other interventions, some of which redress shortcomings in the post-structuralist literature by highlighting the 'polyvocal, polylocal nature of development performances and appropriations' (Sivaramakrishnan and Agrawal 2003:29) on the ground (e.g. Gupta 1998; Li 2007; Moore 1999; Rigg 2012; Yeh 2007). Yet it is striking that many of these works continue to be shaped by the same analytical and theoretical frameworks as post-structuralist critiques, with questions of Foucauldian 'governmentality', citizen/subject-formation and state-society relations tending to dominate their discussions. Through this lens, potentially anything related to development, from virtue to ethics to agriculture, can be shown to have 'a politics' in a suffusive, capillary sense.

Put differently, my argument is not that anthropologists of development have focused excessively on politics in the narrow sense of institutions, hierarchies and power imbalances, but that the subfield, like much political anthropology (Candea 2011), is presently dominated by an analytical perspective that views "political reality... [as] the ground from which everything (even the supposedy non-political) is made_-politically' (ibid.:313). ${ }^{1}$ While this perspective can be tremendously illuminating and productive of new 'postdevelopment' imaginings (e.g. Escobar 2012; Rahnema 1997), it also risks occluding various ethnographic specificities by privileging certain forms, imaginaries and relations (e.g. citizen-subjecthood) over others (e.g. Christian personhood) — some of which may be more salient to the people with whom we work. But what insights and analytical possibilities might be yielded from careful attention to the latter? And what, by extension, might the anthropology of development look like if it didn't take 'the political' as the naturalized, privileged ground of its analysis?

This is not a question of whether to take local idioms and experiences seriously (as anthropologists undoubtedly do), but what taking them seriously entails. To explore through a Foucauldian lens how religious ideas are politicized by development is one thing; to explore 
developmental politics through the lens of ethno-theology, religious ethics or indigenous cosmology is quite another. In the following pages, I adopt the latter approach by treating certain moral dilemmas, mythological imaginings and spiritual conundrums as the very grounds on which my acquaintances encounter development. Briefly, I shall suggest that many villagers affected by the dam-construction and resettlement scheme have enrolled both mythologies of gifting and Christian moralities into a loose but discernible "program of ambiguation' (Battaglia 1997:506), through which they deal with the promises, contradictions, successes and failures of Malaysian developmentalism. I use the term 'ambiguation' here not simply as a gloss for Bidayuhs' ambivalence about development, but-following Debbora Battaglia - as a description of how 'agency is invoked or ascribed, concealed or obfuscated, more or less strategically’ (1997:506) by my acquaintances in various development-related contexts. Such efforts enable them to fragment and multiply the potential meanings and effects of development, thus opening up spaces of hope and possibility through which closure is continually deferred. I shall return to these points later. But first, some ethnography.

\section{Ethnographic contexts}

Living mainly in the hills around the state capital, Kuching, Bidayuhs comprise the secondlargest indigenous group in the Malaysian state of Sarawak. Until the 1970s, they were largely rice cultivators and followers of an animist ritual complex that revolved around the agricultural year. In recent decades, however, Bidayuh villages have become increasingly urbanized and self-consciously 'modern', with most people taking up waged labour and converting to several Christian denominations (see Author 2012a). Today rice cultivation is more of a supplementary than a subsistence activity, and following concerted infrastructural improvements, many villages have effectively become part of Kuching's commuter belt. 
The four villages affected by the dam - among which I have conducted short yearly stints of fieldwork since 2007-constitute an exception to this trend. Originally located in the rainforested hills near the Indonesian border, two to five hours' walk from the road, these villages lack 'modern' amenities such as piped water and grid-supplied electricity, and are inhabited by rice farmers who also earn small incomes cultivating rubber, cocoa and pepper and providing occasional labour for construction projects. Many of them are literate, having received at least primary schooling, and most have spent time living in urban areas, where their friends and family are scattered. In the eyes of state officials - and indeed the local media and many other Bidayuhs - however, they are fundamentally country bumpkins, and thus ideal targets for Sarawak's development apparatus.

\section{$\underline{\text { Sarawakian developmentalism }}$}

Since its independence as part of Malaysia (1963), Sarawak's politics, economy and state identity have been suffused by a vigorous brand of development (pembangunan) that amalgamates a 'muscle-bound', 'high modernist ideology' (Scott 1998:4), technocratic postWar models of international development (Escobar 2012) and a powerful paternalistic state with close links to private enterprise (Cramb 2011; Bissonnette 2011). Many Sarawakian politicians, civil servants and urban denizens see development as both a potent means of transforming the state and nation into prosperous first-world entities and a moral imperative that should be embraced by all its citizens.

Central to Sarawak's developmentalist policies is an ideological dualism between 'native rural society' and 'modern society' (Bissonnette 2011:350). Most of Sarawak's political and community leaders - many of whom grew up in rural villages before joining a self-styled educated urban elite - view the concerted transition from the former to the latter as a linchpin

of pembangunan. From this perspective, shifting cultivation, hunter-gathering and other 
'traditional' livelihoods are counterproductive and backward; a drag on Malaysia's march to modernity. ${ }^{2}$ Concomitantly, those involved in such practices - usually upriver or hill-dwelling indigenous minorities - are portrayed as not-quite-citizens who must be drawn into the mainstream and turned into economically productive (i.e. wage-earning) Sarawakians. Largescale development, in the form of infrastructural improvements, new schools and clinics and wealth-generating opportunities such as oil palm plantations, are seen as pivotal to this projected transformation.

This is the ideological and political framework in which the present dam-construction and resettlement scheme has been embedded. ${ }^{3}$ When opened, the dam will create a reservoir to secure Kuching's water supply until 2030, thereby submerging three village sites and cutting off the fourth. Accordingly, all four communities were earmarked from the start for resettlement — the first wave of which began in December 2013 - to a new government-built township by the road, which comes replete with concrete houses, electricity, piped water and access to clinics, schools and urban jobs. ${ }^{4}$ In keeping with central state policy, each household has been allocated three acres of farmland - a significant reduction from their previous customary land-holdings, which allowed for seven to ten-yearly cycles of shifting cultivation. As various civil servants and urban Bidayuhs have told me, this is a deliberate strategy to wean the villagers off subsistence agriculture, because 'in two or three generations nobody will be growing rice'.

This expectation is mirrored in official descriptions of the scheme in terms of 'progress' (kemajuan), modernization and material welfare. Its political architects portray resettlement as a golden opportunity to escape a backbreaking, impoverished, remote lifestyle and become modern Malaysian citizens. Villagers are thus repositioned as beneficiaries of development, and their willing participation in the scheme taken as proof of their loyalty and commitment to 
the larger nation-building agenda. This was made clear in a fire-and-brimstone speech delivered by a senior cabinet minister at a 2008 ceremony, at which a batch of land compensation cheques were handed out. The proceedings had been delayed by a protest carried out by a small group of villagers who, together with a well-known indigenous rights lawyer and opposition politician, had launched a legal case against the resettlement scheme. Addressing the audience-mainly villagers, journalists and representatives from the government and construction company-the minister proclaimed that this dam wasn't just about these villages but about 'greater Kuching', of which they were part. 'If you don't want water, enough water for greater Kuching, then go ahead and protest!' he boomed. 'If you don't want development and a better future for your children, protest.' He knew, he said more softly, that it was hard for the villagers to leave their place of birth, but this project was important. And most important of all was giving a good future, kemudahan (amenities, facilities) and kemajuan (progress, development) to our children (anak anak kita). Turning to the protesters and their lawyer, he shouted: 'Keep politics out of this! This is beyond politics ... this is something for the people, for the future!'

The gifting aesthetic that structured this ceremony will be discussed later. What I want to underscore here is how Sarawak's development apparatus—rather like James Ferguson's 'antipolitics' machine-depicts pembangunan as an incontrovertible good that floats beyond politics and commercial interests, 'all the while performing, almost unnoticed, its own preeminently political operation of expanding bureaucratic state power (Ferguson 1990:xv). Its insistent futurism, however, also obviates any reference to two of the most divisive and controversial issues in Malaysia today: ethnicity and religion, both of which are critical to understanding Bidayuhs' attitudes towards pembangunan.

\section{Pembangunan and the Kirieng 'problem'}


The Bidayuhs affected by the dam have been severely split over the project, with a significant proportion enthusiastically supporting resettlement, a significant minority rejecting it, and everyone else shuttling in between. However, they all agree on two things: that as selfconscious Malaysian citizens, they genuinely want development and to become modern; and that their aspirations have frequently been thwarted by the ethno-religious configuration of power in contemporary Sarawak.

As one of Malaysia's officially-recognized 'native' groups, Bidayuhs are legally and constitutionally entitled to a range of benefits reserved for bumiputera (literally 'sons of the soil') — a category encompassing Malays and the indigenes of Sarawak and Sabah — including scholarships, special bank accounts and civil service jobs (see King 1988; Siddique and Suryadinata 1981; Watson 1996). In practice, however, most Bidayuhs see themselves as 'second-class' bumiputera in comparison to Malays, who in Malaysia are by definition Muslim. ${ }^{5}$ The Sarawakian situation is further complicated by the political dominance, over the last three decades, of the Melanau Chief Minister, Taib Mahmud. Unlike Sarawak's other indigenous groups, most Melanaus are Muslim, having begun converting to Islam a few centuries ago. Consequently, many Bidayuhs attribute Taib's power and influence to the fact that he is a Muslim who has won the favour of other Muslims - notably the Malays in Kuala Lumpur who 'rule' the country. Tellingly, they consistently describe his government as 'Kirieng' — the term for 'Malay' that also implies 'Muslim' - and frequently draw concerns about Malay-Muslim domination into their discussions of development (pembangunan), the hallmark of Taib's government.

As I explain elsewhere (Author 2007), Bidayuhs have long had a problematic relationship to Islam, which challenges some of their most cherished ideals of sociality and mobility. Since 
independence, however, Malays have effectively become the political masters of Malaysia, and their religion a potent means of obtaining political and economic resources. Melanaus are held up as a quintessential example of advancement-through-Islam, but so too are the few Bidayuhs who convert for what is assumed to be material gain, such as job promotions, cash handouts and - in the case of a Bidayuh village that embraced Islam en masse - tarred roads and gleaming new community buildings. For everyone else, however, obtaining such perks is a more arduous affair. It is a widely repeated axiom (usually illustrated with a personal anecdote), for example, that if ten civil service jobs are advertised for bumiputera, nine will go to Malays/Muslims, even if the other candidates are better qualified.

Such grievances - which form a steady background hum to Bidayuhs' discussions about development - have been amplified in the context of the dam-construction and resettlement project. Regardless of how they view the scheme, the affected villagers broadly concur that the prospect of getting piped water, electricity and access to amenities in the resettlement site is soured by the loss of their villages, crops and land — not to mention the literal price at which 'development' comes. Over the years I have repeatedly heard that 'up here [in the hills], everything is "free" [English]: rice, vegetables, fish, building material.... But down there in the pasar (city), everything requires money: houses, water, electricity, food, even rice'. Echoing her elderly mother's concerns about moving to a 'grave', one lady reflected that without sufficient land, the villagers would not be able to feed themselves and be forced to work as manual labour. Land was their source of livelihood and income, she said; conversely, 'No land, no money' (măting tanah, măting duit).

Such problems are not simply construed in logistical or economic terms, but directly attributed to the Kirieng government's neglect of non-Muslim bumiputera. Most of my acquaintances charge the powers-that-be with only 'caring for' (piduri) their own kindMalays and Muslims - while withholding benefits from others or extending them on highly 
problematic terms. As details of the compensation package were unveiled from 2007, for example, several villagers asked why the government would not let them move further up into the hills — as the Bidayuh MP mentioned earlier had promised—-before bringing development to them. The official response that it was not feasible to extend the road and infrastructure to such a remote, hilly area was batted away. Gesturing towards a nearby mountain on which the government (in partnership with a private company) had created a luxury resort and golf course - and, it was rumoured, built a former Malaysian prime minister a grand house ${ }^{6}$-my companions would ask why the Kirieng government could bring kemudahan over there but not here, just a short distance away. The resort-bound helicopters that occasionally flew noisily overhead merely strengthened their conviction that Bidayuhs and other non-Muslims would inevitably get a raw deal in the grand pembangunan scheme of things.

Such anti-Kirieng resentment, however, is complicated by the fact that Bidayuhs in this area have benefited from certain kinds of pembangunan, including primary schools in two villages, solar panels, funding for the construction and upkeep of their bamboo bridges and gravity-feed water systems, free or subsidised fertilizers and pesticides, and a mother-and-child clinic by the road. Despite feeling chronically marginalized by an adversarial ethno-religious configuration, my acquaintances are also aware that pembangunan can sometimes materialize and succeed, and that exclusion from the perks that they see Kirieng enjoying is not necessarily a fait accompli. In this regard, pembangunan is as much an object of hope as it is an object of desire and disappointment. The challenge for them, I suggest, is how to hold open this space between expectation and reality, into which they slot every pembangunan project that they encounter. The rest of this article explores how they have tackled this challenge by exploring two overlapping zone of moral engagement between Bidayuhs and the state-gifting and Christianity. Each of these is a site at which development is ambiguated: a process, I shall 
argue, that does not resolve the problems posed by pembangunan but actually holds resolution at bay.

\section{The aesthetics and morality of development as a gift}

Shortly before the close of the 2008 compensation ceremony, the villagers were invited to take a picture with the visiting dignitaries. Herded into an awkward cluster, they were urged by the emcee to hold up their cheques for the camera and shout 'terima kasih!' ('thank you!'). The photogarph was duly published in the next day's newspapers, visually immortalizing them as happy beneficiaries of development and committed participants in Malaysia's grand nationbuilding enterprise.

Such images regularly populate both official governmental discourses and the national media. Roads, schools, water supplies and other concrete manifestations of pembangunan are variously depicted as gifts to 'rural folk' (as the local English-language press often styles them) from a benevolent government that rises above political squabbles in its unending quest to uplift its citizens. Meetings between government representatives and their rural constituents are frequently structured by a gifting aesthetic that actualizes rather than simply represents social forms - in this case, the tutelary relationship between 'state' and 'society'. The distribution of cheques, hampers and other 'presents' (hadiah) by ministers is a common feature of such interactions, as are ceremonies to mark the completion of infrastructural projects such as water tanks, community buildings and electricity generators. Such philanthropic gestures are replicated by the government's partners, including oil palm companies and construction firms, which act in an 'image of classic corporate largesse' (Rajak 2008:298) by doling out gifts to local villages and regularly 'sponsoring' community events. The dam construction company, for example, has helped fund the maintenance of bamboo 
suspension bridges in the area and paid for several animist ritual celebrations; at the 2008 compensation ceremony, it also handed out Christmas presents to representatives of the four villages.

The 'moral bonds and coercive properties' (Rajak 2008:301) of such practices in transnational development networks have been critiqued by anthropologists, who highlight the damaging dimensions of power and patronage underlying the rhetoric of the disinterested gift (e.g. Stirrat and Henkel 1997). A similar charge may be levelled at the official philanthropic trope of development-as-gift, which couches pembangunan in a language of paternalism, generosity and affection. Accepting these gifts embroils Bidayuhs not in a formal exchange with their givers but in a moral relationship in which they are expected to reciprocate with their loyalty and cooperation. Most of my acquaintances are aware of this; indeed, they too talk about development as something that the state must 'give' (nyen) or 'bring' (tăban) to them. Such discourses, however, do not simply signal their absorption of developmentalist rhetoric or transformation into dependent subjects of development. Instead, they must also be examined in relation to another historically-inflected set of understandings of benefaction and tutelage.

The notion of being 'given' good things by powerful outsiders-from spirits to colonial visitors to Malaysian politicians - is a widespread motif in Bidayuh thought and history. Origin myths recorded by nineteenth and twentieth-century observers (e.g. Howes 1952:74-76; St John 1974:202-04) and which are still repeated today, for example, reveal how important things like the skill of rice cultivation and the old animist rituals, adat gawai, were originally 'given' to Bidayuhs' ancestors by supernatural beings such as spirits, star-maidens or humans who visited other realms (Lindell 2000:98-99; Nuek 2002:133-41.) Today, gawai practitioners ask various spirit entities to 'give' them coolness, health and safety in return for prayers, ceremonies and offerings; similarly, Christian Bidayuhs routinely petition God and other personages to 'give' them anything from peace to good examination results. But such gifting 
practices are not confined to a cosmological realm. When Sarawak was ruled by the Brooke dynasty (1841-1946) and later the British crown (1946-63), European officials would also be drawn into these relationships through large ceremonies held whenever they passed through Bidayuh villages (Geddes 1954:18; Nuek 2002:103-104; Roth 1980, I:242-44, 245-49, 25051; Walker 2005). Both historical accounts and my fieldwork suggest that these affairs were explicitly transactional: a means by which villagers extracted blessings, potent substances, gifts, tax breaks and other concessions in exchange for their offerings, entertainments and allegiance. Here, gods and governors occupied the same structural niche: they were both types of powerful stranger-beings with the capacity to 'bring' and 'give' good things to Bidayuhs.

This mythico-historical backdrop complicates present-day Bidayuhs' encounters with the trope of development-as-gift. If my acquaintances have incorporated themselves into the gifting framework of state-led development, they have also been 'extending' (Miyazaki 2005) their own myths and notions of gifting to their relations with the government. Many Bidayuhs see the Malaysian state as having stepped into the shoes of the 'British' [English] —a term that encompasses both the Brooke Raj and the Crown - thereby acquiring its responsibilities to its subjects. In this capacity, the present government is expected to give good things to the people - in this case, pembangunan with its promises of modernity, progress and prosperity. The melding of these two frames of reference-the mythico-historical notion of gifting relationships with outsiders and contemporary discourses of development-as-gift—is nicely illustrated by the following account of Sarawak's successive governments, which I was told by some middle-aged men in one of the affected villages.

Long ago, they said, 'Rajah Brooke' brought 'hospital', 'clinic', 'jail', 'court' and 'doctor' (all English) to the pasar (town/city). Rajah Brooke was a kind and generous (măndis) ruler, but these kemudahan did not reach rural areas until the days of 'Confrontation' (1963-65) ${ }^{7}$ - a 
period that many Bidayuhs associate with British rule because of the large number of British troops that got stationed in the region. Kemudahan, they said, started arriving when the soldiers built roads to the areas they had to guard; they also got missionaries to set up clinics, schools and churches. After Confrontation, the British soldiers left and were replaced by Malaysian soldiers. This was when Sarawak became part of Malaysia. ${ }^{8}$ Initially, the Malay government was also kind and generous, but the country still wasn't yet maju (progressive; developed). And then the government started trying to make the country maju. However, the only people who really became maju and got all the kemudahan were the Malays. And this was why Bidayuhs said that the current government was bad (arap): because it only took care of its own race. By contrast, the British did try to make the people maju, even if it wasn't by very much.

This account recasts the history of government in Sarawak in pembangunan-oriented terms, enrolling the actions of the Brooke Raj, the British and Malay(sian) government into a longer narrative of acquiring kemudahan and becoming maju - two concepts central to the contemporary developmentalist milieu. Each successive government's moral character is gauged by its willingness to give its rakyat (citizens/subjects) amenities, progress and development. And on this count, nearly all my acquaintances contend that the current Kirieng government has let them down by refusing to 'bring' development to the hills. Its perceived failure has been underscored by the charitable efforts of several other bodies in the area, notably church groups, the Sai Baba Council, indigenous welfare NGOs and some nature-loving urbanites, such as Hash House Harriers from Kuching. These parties have regularly brought cash, medicines, toys, clothing and even new structures to the uphill villages - 'gifts' that are often held up as proof of the government's refusal to 'care for' Bidayuhs. 'All the kemudahan in this area comes from outside,' a young mother told me, 'but today's YBs [Members of Parliament] have given us nothing.' She added that whereas government officials would tell 
villagers to fill out endless forms to obtain kemudahan, the churches and many NGOs would just hand over the money when asked.

In recent years, their munificence has acquired added significance in the context of two developments: the progressive withdrawal of state involvement in the soon-to-be-inundated villages, and the construction of three new settlements further upland by about a third of the affected households, who are unwilling to move to the resettlement township. These new sites - whose inhabitants are described by other villagers as 'fighting the government' (rawan printah) — have not been officially registered by the state. ${ }^{9}$ However, their establishment has been facilitated by support and donations from NGOs, urban Malaysians and other wellwishers. The leader of the legal case mentioned earlier, for instance, told me that when the state-supplied solar panels in his old village house broke down, the government refused to repair them since everything was about to be submerged-a move that he interpreted as retaliation for his opposition to resettlement. When he and his fellow villagers moved up to their new site, however, they were given a mini-hydroelectric dam by a sympathetic West Malaysian filmmaker and activist who had raised the money through a crowdfunding campaign. This coup - and the growing conviction that where the state forsook them, others would provide-buoyed their confidence in their ability to remain in their new village regardless of the government's reaction.

As important means of obtaining amenities, progress, modernity and other good things, gifts from non-state parties have thus thrown the government's perceived failure to fulfil its historical and moral duties into incriminatory relief. On one level, then, my acquaintances' efforts to cultivate tutelary relationships with outside bodies are profoundly political deeds: critiques of and acts of resistance to the state. But there is more to the story than that. For the affected villagers, contemporary development policies, tropes of progress and relations with the government are also encompassed within a larger moral, temporal and cosmological 
framework that mythologizes development as much as it politicizes mythology. By invoking the generous acts of 'Rajah Brooke' and the British and depicting non-state donations in terms of gifts, kemudahan and maju, my acquaintances are effectively historicizing and deconstructing development: unmooring its fruits, the government and the state from each other. In the process, they destabilize the idea-implicit in official gifting rhetoric - that pembangunan is the preserve of the current ruling coalition. What emerges instead is a picture of pembangunan as an assemblage of benefits and amenities that the state ought rightfully to provide but that, crucially, can be attained through other means.

Consequently, many of the affected villagers do not construe their current marginality as set in stone, but as a historically-specific condition that can be overcome and may change in time. If current politicians refuse to bring electricity and piped water to the hills, villagers can turn to other benevolent outsiders for help. Although the present Malay(sian) government has reneged on the state's historical moral obligation to give development to Bidayuhs, things may change with a new government, as they did in the past. This sense of constant possibility may help to explain why, apart from some staunch opponents of resettlement, many villagers continue to invest time, effort and hope in their relationships with government officials such as the Bidayuh politician mentioned earlier. I would argue that rather than reflecting simpleminded devotion or desperation (as some urban Sarawakians suggest), that these efforts entail a commitment to a moral relationship with an ideal state in which they have never fully lost faith. In these moments, rural Bidayuhs 'evacuate' (Guyer 2007) the problems and disappointments of the present while holding firmly to an older, timeless model of gifting and moral tutelage that allows them to imagine a better future.

Everyday reality, however, has often proved disappointing. When the people involved in the anti-resettlement case moved to their new village uphill, for example, they approached the Anglican church in Kuching (which had 'sponsored' the cement chapel in their old village) for 
funding to build another chapel onsite. Their request was rebuffed because, according to my acquaintances, the Anglican authorities were unwilling to be seen to support the group that was 'fighting the government'. In these moments, the non-extensibility of the trope of the gift becomes painfully evident (cf. Miyazaki 2005), as does the very real power of the present government. Faced with these and similar frustrations, some Bidayuhs have turned to other frames of meaning and morality, chief among them Christianity—arguably the most important addition to Bidayuh life in the last half-century.

\section{Munificence and morality in Bidayuh Christianity}

Like their lowland counterparts, the Bidayuhs affected by the dam encountered Christianity well before converting to it. Anglican, and later Catholic and other missionaries, first entered Sarawak in the mid-nineteenth century under the auspices of the Brooke Raj. These missions effectively acted as altruistic wings of the state, establishing medical stations and classes in rural areas that catered to all comers, Christian and otherwise. Many missionaries became wellversed in local languages, customs and rituals and established convivial ties with the indigenous populations. Bridge-builders rather than idol-smashers, they helped to forge what has largely remained a highly accommodating, non-rupturous form of Bidayuh Christianity (Author 2012b).

For reasons on which I cannot elaborate here (see Author 2012a), conversion to Anglicanism among the affected villages mostly took place between the 1960s and 80s, with a further small wave of 'internal conversion' to the evangelical SIB in the 1990s. Despite the minor differences between them, members of both congregations as well as the remaining animist practitioners all speak of Christianity as a fundamentally munificent entity. Many of them, particularly the 
older generation, have fond memories of earlier missionaries who, they recall, were always 'bringing' medicines, cash, books and kemudahan (such as a water tank) to the villages. In this respect, they view the Christian missions and their successors, the parish churches, as of a piece with old spirits, the Brookes and the British: as benevolent outside 'givers' of good things to Bidayuhs.

This notion of benefaction also infuses the ethno-theology and ritual practices of both Anglicans and SIBs, for whom supplication is essential to prayer (but cf. Author 2012a:16974). My acquaintances' interactions with God or Jesus frequently involve petitions for mundane objectives such as cures for illnesses, jobs and good farming weather and larger concerns such as peace, safety and freedom from fear. Such entreaties, however, are less explicitly transactional than those of the ideal gifting framework discussed earlier. Although God, Jesus and the Holy Spirit have been partially mapped onto the older figure of the munificent outsider, their relationships with Bidayuhs are couched in a distinctively Christian idiom of love. As I explain elsewhere (Author 2012a: Chapter 6), God's gifts to humankindincluding the life of His son, Jesus - are construed by many Bidayuhs as a selfless act of love that can never be fully repaid. Christians cannot reciprocate equally but can only love God in return, and manifest that love through relations with their fellow human beings. Layered onto this framework of loving and gifting, however, is another characteristically Christian concept: that of sin. If loving each other reaffirms and reconstitutes one's relationship with God, then sinning - doing what is not proper (patut) to Christian convention-is an abrogation of that relationship; a refusal to behave as part of God's ideal household (rawang).

In many cases, Christians can be steered away from sin through the censure of their peers (Author 2012b). However, the ultimate responsibility for sinning and atoning lies with the 
reflexive individual, which in both pre-Christian and Christian understanding is the locus of moral agency. In other words, sinning implies and indeed demands a particular selfconsciousness that gives individual Christians the capacity to reflect upon and regulate their own behaviour. ${ }^{10}$ And it is on this point that we can return to the ethnography. As mentioned earlier, the affected villagers overwhelmingly describe the dam-construction and resettlement scheme in pembangunan-oriented terms, inflected as they are by both idealized notions of gifting and the problem of Malay-Muslim political dominance. But whereas the proresettlement villagers tend to leave it at that, those who are opposed to or at least leery about resettlement have imbricated such discussions with the Christian moral concepts explored above.

In the last few years, I have sometimes heard the latter accusing the former of chasing money - that is, the government's sizeable compensation cheques - at the expense of their own land and community (kaum). Such actions are construed as a (sinful) betrayal of their responsibilities to their fellow villagers and Christians, and thus as a blemish on their relationship with God. Implicit in such criticisms, however, is also a question of the moral rectitude of the individual - that reflexive, decision-making self that others can influence but not compel into doing anything. When a village elder and proponent of resettlement arrived at a Sunday prayer service looking unusually surly, for example, the woman next to me whispered that perhaps his atin (heart, inner spirit) was troubled because of his recent behaviourimplying that entering the presence of God had pricked his conscience. On another occasion, I was surprised to discover that one of the village heads - a confident, articulate and politically savvy supporter of resettlement- had been reduced to tears during a late-night visit from his distant relative, the prayer leader of a neighbouring village and leading member of the antiresettlement group. Although I never broached this matter with the village head, his interlocutor 
later told me that he asked the former to reflect on how he had sold out and caused suffering to his kin and neighbours. In his eyes, the village head broke down because he was suddenly-if only momentarily—made to face his internal guilt.

Ruminations such as these reiterate the belief that moral responsibility and culpability are properties of the individual self: a familiar theme to both anthropologists of Christianity followers of adat gawai, which has analogous moral templates (see Author 2012b). The corollary to this understanding is that the outcomes of major moral dilemmas can never be foregone conclusions, because it is impossible to predict how individuals might respond. I suggest that Christianity helps to alleviate this pervasive sense of indeterminacy not by providing certainty, but by reframing uncertainty as inherent to individual and collective existence. When discussing others' engagements with the scheme, my acquaintances often ask rhetorically, 'Who knows what's in there?' To an extent, such reflections constitute veiled acknowledgements of their limited moral influence on their peers and the consoling thought that all individuals are ultimately accountable to God for their choices. But I suggest that they also help to alleviate a poignant problem for which that oft-cited villain, Malay-Muslim dominance, cannot be blamed. This is the fact that some of the most acrimonious divisions in recent years have not been between Bidayuhs and political, ethnic or religious 'others', but between Bidayuhs themselves - not only within the affected communities but also between them and the politicians who have relentlessly supported the project.

Such figures are often criticised by the villagers for profiting from state politics and development spinoffs at the expense of their fellow Bidayuhs. In the run-up to resettlement, for example, the affected villages were abuzz with rumours that the area around the dam would be gazetted as a national park and a resort built near the reservoir to attract eco-tourists, with 
politicians parcelling out the profits among themselves. Regardless of their accuracy, these rumours fanned the villagers' anger at the perceived behaviour of their politicians. Without recourse to an anti-Muslim critique, some of my acquaintances have depicted their actions in terms of an individual failure to live up to Christian ideals. In recent years, comments such as 'He [Bidayuh politician] calls himself Christian, but look at what he's doing to his own people!' have peppered my fieldwork, while a comment in English on a Sarawakian blog post criticising the dam reads:

To those Bidayuh leaders/BN [Barisan Nasional, the ruling coalition] goons do not think highly of yourself in defending BN policies when it is clearly killing your own Bidayuh folks. [...]

Wonder what kind of Christians are these Bidayuh BN goons? Far from what Jesus teaching! $[\ldots]$

Bidayuh folks must get their head right this time: stop voting the $\mathrm{BN}$ evil looters and be a responsible Christians [sic]. Help, defend the poor Bidayuhs like what Jesus always did, not kill them for BN greed. [...]

Show us in the Bible where Jesus support corruption to justify the votes for BN!

While unusually verbose, this post encapsulates much of the anger and confusion that has characterised my acquaintances' views on Bidayuh politicians in recent years. Like contemplations on individual Christians' moral integrity and choices, such discussions extend the moral boundaries of development beyond the state, thus rendering its proponents responsible to a greater, cosmological moral agency. At times, as happened when the politician mentioned earlier got cancer, divine reckoning can appear fairly immediate. In many other cases, however, my acquaintances can only cast their thoughts towards a vague future-one 
defined by soteriological rather than 'everyday' time - and hope that individuals' personal consciences will move them to act differently.

\section{Conclusion}

During an Anglican prayer gathering, I was told a joke by one of the men in attendance. All Malaysians are familiar with the image of the first Prime Minister, the Malay politician, Tunku Abdul Rahman, raising his fist and shouting 'Merdeka!'- 'freedom!' or 'independence!'when British rule ended in what is now West Malaysia. ${ }^{11}$ But what most people didn't know, said my interlocutor, quite deadpan, was that as he did so, an oil palm sprouted from his hand. ${ }^{12}$

This joke played on a familiar folkloric theme of metamorphosis (barui) as well as Bidayuhs' widespread view of rural development as a poisoned gift that often entails becoming manual labour on commercial plantations. Subversive yet non-confrontational, it reflects the complicated jumble of feelings that characterises my acquaintances' engagements with Malaysia's grand developmentalist vision. Despite their sense of chronic marginalization, many Bidayuhs' desire for pembangunan and insistence that the state should 'give' it to them remain unabated. Each successive project is therefore approached with the same cagey optimism that maybe this time, things will work. What I have tried to flesh out in this article, however, is not simply their deep-seated ambivalence about development, but the moral, ethical and religious means through which they have sought to render it ambiguous. One problem in the compensation package, for example, could be due to the state's systematic discrimination against non-Muslims - or it could be due to the personal greed of a Bidayuh politician. Conversely, an unexpected concession might be attributed to a merciful God's interventionor taken as proof that pembangunan sometimes does work, as it has in the past. 
By collapsing contemporary Sarawakian developmentalism and Malaysian citizenship into mythico-historical frameworks of gifting and benevolent statehood, then, these Bidayuhs simultaneously decouple the fruits of development—amenities, progress, modernity and so on-from the current government, thus making it possible to pursue alternative gifting relations and to imagine a future in which things will be different. By turning individual choices into matters of Christian ethics, they expand the moral and temporal scope of development, thereby recasting opposition to certain state-led schemes as righteous and godly rather than selfish and regressive, as politicians portray it. Cumulatively, these efforts to pull apart intentions, mechanisms, objects, parties and effects constitute a 'working poetics of ambiguity' (Battaglia 1997:507) that destabilizes any sense of pembangunan's coherence or singularity for both Bidayuhs and their analytical observers. In the process, it enables my acquaintances to continually muddy their situation rather than resolve it; to prevent their pembangunan 'story'hitherto marked by more fears and disappointments than successes - from coming to an end by holding in suspension the possibility that things will one day work out. This constant sense of 'maybe, perhaps, what if?' engenders both hope and despair, but the one thing that it does not generate is closure.

This brings me to some recursive closing points. From a certain perspective, my ethnography could be read as a classic example of how marginalized minorities negotiate their status as citizen-subjects and make claims on the state through national development projects. What I have tried to do, however, is approach the dam-construction and resettlement scheme from a different angle that shows not only how myths and religion become political or 'developmentalized', but also how development itself has become mythologized and religious. This is not an analytical sleight-of-hand, but a move to tease open new possibilities for the 
contemporary anthropology of development. First, resisting the (still compelling) analytical impulse to approach development as an priori political matter can clear a space for apprehending ethnographic phenomena such as Christian personhood, ethno-theological templates and temporal models on their own terms - as thoroughly 'cultural' (Robbins 2007) grounds on which people act in and engage the world - rather than as refractions of a larger ontological political reality visible only to the analyst (Yarrow and Venkatesan 2012:4-5). Instead of simply examining how Bidayuhs have deployed Christian understandings of love and self-regulation in negotiating their status as citizen-subjects, for example, one might ask how the dam project has become embedded in a Christian framework that in many ways trumps Bidayuhs' allegiance to Malaysia's developmentalist state. A host of questions follows: How might Bidayuh Christians render specific occurrences, such as a politician's illness or compensation problems, spiritual or cosmological? How are the bureaucratic rhythms of development projects incorporated into 'soteriological time' (see also Robbins 2007)? How might 'faith' act as 'the conceptual fuel for the prospect of change' (Bornstein 2005:7)? What, indeed, might a Bidayuh Christian account of development look like?

This shift in perspective demands a concomitant commitment to tracing ethnographic connections and relations that fall outside the conventional remit of anthropologies of development. For Bidayuhs, these include global Christian networks and notions of fellowship, soteriological debates and evolving ritual bonds-all vital conceptual and praxiological resources on which my acquaintances regularly draw, and that far exceed the parameters of this particular dam-construction project. Taking these seriously as frames of action and meaning demands an open-ended commitment to allowing emergent ethnographic phenomena to 'dictate the terms of their own analysis' (Henare, Holbraad and Wastell 2007:4) rather than turning them into objects of a politicizing gaze. Such a move, I suggest, can help push the 
anthropology of development 'beyond critique' by holding open a space for ambiguity, hope (Miyazaki 2004), faith (Bornstein 2005), desire (High 2014) and possibility ${ }^{13}$ — not only as thematic issues but also as potential analytic devices. At the same time, it may inspire anthropologists of development to reach past questions of governmentality, citizenship and political theory towards more concerted dialogues with other anthropological subfields and theories - a shift already occurring in the growing literature on faith-based development (e.g. (e.g. Atia 2011; Bornstein 2005; Jacka 2005; Freeman 2012; Occhipinti 2005). None of this, however, means that anthropologies of development should gravitate away from politics or political theory. Rather, just as post-structuralist critiques introduced a whole new political sensibility to understandings of development, perhaps the time is now ripe for an imaginative reworking of prevailing understandings of 'the political'-along with the very boundaries of this subfield.

Notes

${ }^{1}$ See Candea 2011's discussion of this tendency in political anthropology more broadly.

${ }^{2}$ For similar trends across Southeast Asia, see, e.g. Duncan 2004; Li 2007; Rosaldo 2003; Tsing 1993.

${ }^{3}$ Owing to the sensitive nature of this (still unfolding) project, this article contains no specific references to the dam or the people involved in it.

${ }^{4}$ At the time of writing (September 2014), about two-thirds of the affected villagers have moved to the government's resettlement site or other urban areas. However, a significant number of households have built new villages on their own customary lands above the inundation zone. Many resettled villagers also visit their old farms and fruit trees regularly, and will do so until inundation takes place. 
${ }^{5}$ Indeed, Malays are constitutionally defined as Muslim in Malaysia; the two categories are, in theory, conflated (Author 2007, 2012a: Chapter 4).

${ }^{6}$ The house was in fact a gift from the construction company to this individual.

${ }^{7}$ In 1963, Indonesia's President Sukarno declared a policy of 'Confrontation' against the new Federation of Malaysia in protest at its incorporation of the Bornean states of Sarawak and Sabah. This sparked off a lengthy border war in Borneo involving incursions into Malaysian territory by Indonesian forces and guerrillas. Britain and other Commonwealth countries sent troops, aircraft and warships to Malaysia's defence, and their presence was widely remembered by villagers living along the borders. 'Confrontation' petered out after Sukarno was deposed in 1965; a peace treaty was signed in August 1966.

${ }^{8}$ Note the slight chronological mismatch here: Sarawak gained independence as part of Malaysia in 1963, whereas Confrontation formally ended in 1966.

${ }^{9}$ In May 2014, however, inhabitants of one of the new villages - those who staged the protest at the cheque compensation ceremony —won their legal case, thus obliging the Sarawak government to recognize their native customary land rights in the area.

${ }^{10} \mathrm{Cf}$. Bornstein 2005, who discusses the parallels between idea of individual 'choice' in Protestant and neo-liberal thought.

${ }^{11}$ The Malay Peninsula gained independence as Malaya in 1957; the Federation of Malaysia was later formed by the merger of Malaya and Sarawak, Sabah and (briefly) Singapore in 1963.

${ }^{12}$ An anonymous reviewer suggested that this alluded to the current RM50 note, which bears side-by-side images of an oil palm and Tunku Abdul Rahman with his arm raised. Although this visual juxtaposition has been noted in other fieldwork conversations, it was not mentioned during this particular exchange. 
${ }^{13}$ Indeed, Guyer has argued for the recognition of 'possibility' as a powerful motif in anthropology's modern history: one that has enabled anthropologists to 'reopen questions and justify grappling with dangers' (2009:357). 


\section{References}

Atia, Mona. 2012. 'A Way to Paradise': Pious Neoliberalism, Islam, and Faith-Based

Development'. Annals of the Association of American Geographers, DOI:

$10.1080 / 00045608.2011 .627046$.

Battaglia, Debbora. 1997. Ambiguating Agency: The Case of Malinowski’s Ghost. American Anthropologist 99(3):505-510.

Bissonnette, Jean-François. 2011. Representations as Practices: Producing a Native Space in Sarawak, Malaysia. Journal of Cultural Geography 28(2):339-63.

Bornstein, Erica. 2005. The Spirit of Development: Protestant NGOs, Morality, and Economics in Zimbabwe. Stanford: Stanford University Press.

Candea, Matei. 2011. 'Our Division of the Universe': Making a Space for the Non-Political in the Anthropology of Politics. Current Anthropology 52(3):309-34.

Cramb, R.A. 2011. Re-inventing Dualism: Policy Narratives and Modes of Oil Palm Expansion in Sarawak, East Malaysia. Journal of Development Studies 47(2):274-93.

Crush, Jonathan. 1995. Power of Development. London and New York: Routledge.

Duncan, Christopher R., ed. 2004. Civilizing the Margins: Southeast Asian Government Policies for the Development of Minorities. Ithaca: Cornell University Press.

Escobar, Arturo. 1995. Encountering Development: The Making and Unmaking of the Third World. Princeton and Oxford: Princeton University Press.

Ferguson, James. 1990. The Anti-Politics Machine: 'Development', Depoliticization, and Bureaucratic Power in Lesotho. Cambridge: Cambridge University Press, 1990. 
Freeman, Dena, ed. 2012. Pentecostalism and Development: Churches, Ngos and Social Change in Africa. New York: Palgrave Macmillan.

Geddes, William. 1954. The Land Dayaks of Sarawak: A Report on a Social Economic Survey of the Land Dayaks of Sarawak Presented to the Colonial Social Science Research Council. London: HM Stationery Office for the Colonial Office.

Grillo, Ralph D. and Roderick L. Stirrat, eds. 1997. Discourses of Development: Anthropological Perspectives . Oxford and New York: Berg.

Gupta, Akhil. 1998. Postcolonial Developments: Agriculture in the Making of Modern India. Durham: Duke University Press.

Guyer, Jane I. 2007. Prophecy and the Near Future: Thoughts on Macroeconomic, Evangelical, and Punctuated Time. American Ethnologist 34(3):409-21.

---2009. On 'possibility': A response to 'How Is Anthropology Going?'. Anthropological Theory 9:355-70.

Henare, Amiria, Martin Holbraad and Sari Wastell. 2007. Introduction to Thinking Through Things: Theorising Artefacts Ethnographically, 1-31. London: Routledge.

High, Holly. 2014. Fields of Desire: Poverty and Policy in Laos. Singapore: NUS Press.

Howes, Peter H.H. 1952. Shǔn Nyamba Nang (A Collection of Land Dayak Stories). London: Macmillan \& Co.

Jacka, Jerry K. 2005. Emplacement and Millennial Expectations in an Era of Development and Globalization: Heaven and the Appeal of Christianity for the Ipili. American Anthropologist 107(4):643-53. 
King, Victor T. 1988. Models and Realities: Malaysian National Planning and East

Malaysian Development Problems. Modern Asian Studies 22(2):263-98.

Li, Tania M. 2007. The Will to Improve: Governmentality, Development, and the Practice of Politics. Durham, NC: Duke University Press.

Lindell, Pamela N. 2000. The Longhouse and the Legacy of History: Religion, Architecture, and Change Among the Bisingai of Sarawak (Malaysia). Unpublished doctoral dissertation. University of Nevada, Reno.

Miyazaki, Hirokazu. 2004. The Method of Hope: Anthropology, Philosophy, and Fijian Knowledge. Stanford: Stanford University Press.

---. 2005. From Sugar Cane to 'Swords': Hope and the Extensibility of the Gift in Fiji. Journal of the Royal Anthropological Institute 11:277-95.

Moore, Donald S. 1999. The Crucible of Cultural Politics: Reworking Development in Zimbabwe's Eastern Highlands. American Ethnologist 26(3):654-89.

Nuek, Patrick R. 2002. A Dayak Bidayuh Community: Rituals, Ceremonies and Festivals. Kuching: Lee Ming Press.

Occhipinti, Laurie A. 2005. Acting on Faith: Religious Development Organizations in Northwestern Argentina. Lanham, MD: Lexington Books.

Rahnema, Majid. 1997. Towards Post-Development: Searching for Signposts, a New Language and New Paradigms. In The Post-Development Reader, edited by Majid Rahnema and Victoria Bawtree, 377-403. London: Zed Books. 
Rajak, Dinah. 2008. 'Uplift and Empower': The Market, Morality and Corporate Responsibility on South Africa's Platinum Belt. Research in Economic Anthropology 28:297324.

Rigg, Jonathan. 2012. Unplanned Development: Tracking Change in South-East Asia. London: Zed Books.

Robbins, Joel. 2007. Continuity Thinking and the Problem of Christian Culture: Belief, Time, and the Anthropology of Christianity. Current Anthropology 48(1):5-38.

Rosaldo, Renato, ed. 2003. Cultural Citizenship in Island Southeast Asia: Nation and Belonging in the Hinterlands. Berkeley, Los Angeles, and London: University of California Press.

Roth, Henry L. 1980 [1896]. The Natives of Sarawak and British North Borneo. 2 Vols. Kuala Lumpur: University of Malaya Press.

Sachs, Wolfgang, ed. 1992. The Development Dictionary: A Guide to Knowledge as Power. London: Zed Books.

Scott, James. 1998. Seeing Like A State: How Certain Schemes to Improve the Human Condition Have Failed. New Haven: Yale University Press.

Siddique, Sharon and Leo Suryadinata. 1981. Bumiputra and Pribumi: Economic Nationalism (Indiginism) in Malaysia and Indonesia. Pacific Affairs 54(4):662-87.

Sivaramakrishnan, K. and Arun Agrawal. 2003. Regional Modernities in Stories and Practices of Development. Introduction to Regional Modernities: The Cultural Politics of Development in India, edited by K. Sivaramakrishnan and Arun Agrawal, 1-61. Stanford: Stanford University Press. 
St John, Spencer. 1974. [1862]. Life in the Forests of the Far East. 2 vols. Kuala Lumpur:

Oxford University Press.

Stirrat, R.L. and Heiko Henkel. 1997. The Development Gift: The Problem of Reciprocity in the NGO World. Annals of the American Academy of Political and Social Science 554:66-80.

Tsing, Anna L. 1993. In the Realm of the Diamond Queen: Marginality in an Out-of-the-Way Place. Princeton: Princeton University Press.

Ver Beek, Kurt A. 2000. Spirituality: a Development Taboo. Development in Practice $10(1): 31-43$.

Walker, John H. 2002. Power and Prowess: The Origins of Brooke Kingship in Sarawak.

Crows Nest: Allen and Unwin, and Honolulu: University of Hawaii Press.

Watson, Charles W. 1996. Reconstructing Malay Identity. Anthropology Today 12(5):10-14.

Yarrow, Thomas and Soumhya Venkatesan. 2012. Anthropology and Development: Critical Framings. Introduction to Differentiating Development: Beyond an Anthropology of Critique, edited by Soumhya Venkatesan and Thomas Yarrow, 1-20. New York and Oxford: Berghahn.

Yeh, Emily T. 2007. Tropes of Indolence and the Cultural Politics of Development in Lhasa, Tibet. Annals of the Association of American Geographers 97(3):593-612. 